\title{
Importancia de los interferones tipo I en la respuesta inmune antiviral contra el Virus del Papiloma Humano
}

\section{Importance of type I interferons in the antiviral immune response against the Human Papillomavirus}

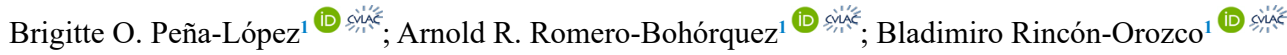

Forma de citar: Peña-López BO, Romero-Bohórquez AR, Rincón-Orozco B. Importancia de los interferones tipo I en la respuesta inmune antiviral contra el Virus del Papiloma Humano. Salud UIS. 2021; e21034. doi:

https://doi.org/10.18273/Saluduis.53.e:21034 (c) (i)

\section{Resumen}

Los interferones (IFNs) son citoquinas fundamentales en la modulación de la inmunidad innata y adaptativa del hospedero, el papel de los IFNs tipo I en el control de la infección por el Virus del Papiloma Humano (VPH) es crucial para una eficiente respuesta antiviral del huésped. Esta revisión profundiza sobre las funciones de los IFNs tipo I en la infección causada por el VPH y los mecanismos de evasión de este virus para inactivar los IFNs tipo I, todos estos mecanismos necesarios para el desarrollo y progresión de lesiones malignas en los tejidos infectados por el VPH.

Palabras clave: VPH; Neoplasias del Cuello Uterino; Interferones Tipo I; Sistema Inmunológico

\begin{abstract}
The interferons (IFNs) are very important cytokines in the interface between innate and adaptive immunity of the host, the role type I IFNs in the control of HPV is pivotal for an efficient immune response, so a wide knowledge about this topic will contribute understanding HPV pathogenicity mechanism. This review focuses on the HPV evasion mechanisms for the type I IFNs which are necessary for a malignant lesion development, otherwise develops knowledge about the type I IFNs functions on the HPV infection.
\end{abstract}

Keywords: HPV; Uterine Cervical Neoplasms; Interferons Type I; Immune System

1. Universidad Industrial de Santander. Colombia.

Correspondencia: Bladimiro Rincón Orozco. Dirección: Facultad de Salud UIS; Carrera 32 29-31. Teléfono: +607 6344000 ext: 3536. Correo electrónico: blrincon@uis.edu.co 


\section{Introducción}

La modulación de los procesos proinflamatorios en tumores malignos asociados con VPH es compleja, ya que implica respuestas inmunes deficientes que posibilitan la persistencia viral induciendo la progresión de las lesiones neoplásicas en el cuello uterino propiciando un microambiente protumoral ${ }^{1,2}$. La activación de la respuesta inmune innata representa la primera respuesta del sistema inmunitario contra la infección por VPH y es esencial para iniciar una inmunidad adaptativa de larga duración, específica y efectiva ${ }^{3}$.

Los IFNs tipo I son citoquinas fundamentales para iniciar una respuesta inmune eficaz contra infecciones virales como el $\mathrm{VPH}^{4}$. El IFN kappa (IFN-א) tiene efectos modulatorios anti-virales, se expresa constitutivamente en los queratinocitos y el IFN épsilon (IFN-E), posee funciones antivirales únicas en la mucosa reproductiva; estos IFNs pueden ser determinantes en el control de la infección por $\mathrm{VPH}^{5-8}$.

Sin embargo, se ha comprobado que los VPH de Alto Riesgo (VPH-AR) han desarrollado mecanismos muy eficientes de evasión inmunológica ${ }^{9}$, por lo tanto, es importante comprender cómo la infección por VPH modula los procesos inmunológicos de los queratinocitos infectados al favorecer la propagación viral y determinando el desarrollo del tumor, la resistencia al tratamiento y el pronóstico general de los pacientes con cánceres asociados a $\mathrm{VPH}^{10-12}$.

Este virus oncogénico tiene la capacidad de modular la función de muchas moléculas involucradas en la vía de señalización de los interferones (IFNs) ${ }^{13}$, un ejemplo es la desregulación de la familia STAT (Transductor de Señal y Activador de la Transcripción), que participa no sólo en procesos de inmunidad, sino también en la proliferación, apoptosis y diferenciación celular ${ }^{14}$, esto podría explicar parcialmente por qué una parte de las infecciones por VPH pueden persistir en los hospederos sin iniciar una respuesta inmune efectiva y evolucionar a cáncer.

La terapia exitosa contra el cáncer y la eficaz estratificación individual de los pacientes con cáncer requieren una comprensión completa de la compleja interacción entre las infecciones persistentes con virus oncogénicos, las vías inflamatorias inducidas, el metabolismo de las células cancerosas, los resultados clínicos y la resistencia terapéutica ${ }^{15,16}$. Hasta ahora, estas conexiones no son bien comprendidas. El objetivo de esta revisión es profundizar sobre las funciones de los IFNs tipo I en la infección causada por el VPH y los mecanismos de evasión de este virus para inactivar los IFNs tipo I.

\section{Generalidades}

Los oncovirus a través de sus oncogenes promueven algunas de las características distintivas del cáncer que, sumadas a otros factores como la inmunosupresión o la inflamación crónica, pueden conducir al establecimiento de malignidades. En general, se estima que los oncovirus causan cerca del $12 \%$ de todos los cánceres humanos a nivel mundial, siendo particularmente el VPH el responsable del $5 \%$ de estos cánceres ${ }^{17-19}$.

El VPH se transmite principalmente a través del contacto sexual y es la infección viral más común del sistema reproductivo ${ }^{20}$. Aproximadamente, entre el 50 y el $80 \%$ de las personas sexualmente activas se infectan con uno o múltiples genotipos de VPH en algún momento o repetidamente durante sus vidas ${ }^{21}$. Normalmente, estas infecciones son eliminadas efectivamente por el sistema inmunológico; no obstante, un porcentaje de personas no puede controlar la infección que finalmente resulta en la aparición de lesiones premalignas que pueden progresar a cáncer ${ }^{22}$. La infección crónica con VPH-AR es la causa del Cáncer de Cuello Uterino (CCU) y se ha asociado a otros cánceres anogenitales, así como a cánceres de cabeza y cuello ${ }^{23}$.

El CCU es el cuarto cáncer femenino más frecuente a nivel mundial y el segundo más común en mujeres que viven en países de bajos y medianos ingresos, reportándose para el año 2018 un estimado de 570000 casos de los cuales más de 300000 tuvieron un desenlace fatal ${ }^{20}$. En Sudamérica, anualmente hay 40000 casos nuevos de CCU de los cuáles más de 19000 resultan mortales ${ }^{24}$, para el caso de Colombia se estima que hay alrededor de 4000 casos anuales con casi 2000 muertes a causa de este tipo de cáncer ${ }^{25}$. Se ha establecido que la incidencia anual de CCU es de 18,7 casos por cada 100000 mujeres, siendo la primera causa de muerte por cáncer entre mujeres colombianas de 30 a 59 años, con aproximadamente 5 muertes diarias por esta enfermedad ${ }^{26}$.

\section{Interferones}

Los IFNs fueron descritos por primera vez hace más de 60 años por Isaacs y Lindenmann quienes observaron que los fluidos de los cultivos celulares infectados 
por virus contenían una proteína celular específica que podía reaccionar con las células para hacerlas resistentes a la infección por virus ${ }^{27}$.

Se conocen numerosos subtipos de IFNs en humanos con funciones especialmente implicadas en la respuesta antiviral ${ }^{27-29}$. Estas funciones son direccionadas por el tipo de receptor, su distribución celular y por las vías de transducción de señales, que una vez activadas promueven la transcripción de más de 2000 genes estimulados por IFN (ISGs) ${ }^{30-34}$. Las proteínas expresadas a partir de estas vías tienen la capacidad de impedir el correcto desarrollo viral: desde la entrada y replicación hasta el ensamblaje y la liberación del virus ${ }^{28,33}$.

\section{Propiedades y clasificación de los IFNs}

Los IFNs son pequeñas glicoproteínas monocatenarias que pertenecen a la familia de las citoquinas. Se componen de 130 a 170 aminoácidos; son activos a bajas concentraciones, tienen acción autocrina y paracrina; son estables en un amplio rango de $\mathrm{pH}$; son menos estables cuando se someten a altas temperaturas y se degradan fácilmente por proteasas, dietil, cloroformo y cetonas $^{35-37}$. Además, la receptividad al IFN puede variar durante el día, dado que los receptores de IFN exhiben una expresión circadiana, siendo su nivel de expresión mayor en la noche que durante el día ${ }^{38}$.

Son secretados por células hospedadoras que actúan como sistema inmune innato en la primera línea de defensa contra componentes extraños de tumores, antígenos y patógenos como bacterias, parásitos y virus $^{4}$. La producción inicial de IFNs no protege directamente, sino que reacciona con receptores específicos en las superficies celulares para activar señales de transducción citoplásmica que luego ingresan al núcleo para estimular genes celulares que codifican una cantidad de proteínas efectoras que conducen a las acciones de defensa ${ }^{4,39}$.

Antiguamente los IFNs se clasificaban según su origen celular en: IFN- $\alpha$ si eran originados a partir de leucocitos; IFN- $\beta$ a partir de fibroblastos; e IFN- $\gamma$ a partir de linfocitos $T$ activados. Sin embargo, en 2003 se descubrió el IFN- $\lambda$ y no se pudo clasificar en ninguna de las categorías preestablecidas ${ }^{40}$.

Actualmente, los IFNs se clasifican en tres clases dependiendo del receptor a través del cual transmiten una señal intracelularmente: los IFNs tipo I comprendidos por IFN $\alpha$ y sus 13 subtipos, IFN- $\beta,-\varepsilon,-\kappa,-\tau,-\delta,-\zeta$, $-\omega$ y $-v$; el IFN tipo II o IFN- $\gamma$; y los IFNs tipo III que comprenden los IFN- $\lambda 1,-\lambda 2$ y $-\lambda 3^{29,41,42}$.

\section{Señalización intracelular de los IFNs}

Los receptores de reconocimiento de patrones (RRP) intracelulares y de superficie celular, como los receptores tipo Toll (TLR) y los receptores tipo RIG-I (RLR), se encargan de reconocer ácidos nucleicos extraños, otros productos microbianos y el ADN propio para inducir los genes que codifican los IFNs tipo I ${ }^{43}$.

Las funciones de los IFNs son direccionadas por el tipo de receptor, su distribución celular y por las múltiples vías de transducción de señales que una vez activadas promueven la transcripción de más de 2000 genes estimulados por IFN (ISGs), abarcando un gran espectro de efectos biológicos ${ }^{30-34}$. La señalización del IFN es específica de la célula y muestra una gran diversidad y complejidad ${ }^{39}$. Las proteínas expresadas a partir de estas vías tienen la capacidad de impedir el correcto desarrollo viral, desde la entrada y replicación hasta el ensamblaje y la liberación del virus ${ }^{28,33}$. A continuación, se resumen las principales vías de señalización relacionadas con los IFNs tipo I y se ilustran en la Figura 1.

\section{Vía de señalización canónica JAK/STAT}

Los IFNs tipo I interactúan y activan los receptores de la superficie celular 1 y 2 (IFNAR1 e IFNAR2). La unión de IFNAR activa las proteínas Janus quinasa 1 (JAK1) y tirosina quinasa 2 (TYK2), estas proteínas se autofosforilan y fosforilan al receptor conduciendo a la dimerización de las proteínas citoplasmáticas transductoras de señal y activadoras de la transcripción 1 y 2 (STAT- 1 y STAT-2) ${ }^{43}$.

Posteriormente, los dímeros de STAT se translocan al núcleo y se unen al factor regulador de IFN 9 (IRF9) formando el complejo de Factor 3 de Genes Estimulados por IFN (ISGF3). Este complejo se une a los elementos de respuesta estimulados por IFN (ISRE) que son secuencias consenso de ADN que actúan en cis en los promotores de ISG, lo que finalmente promueve una alta transcripción de los ISGs ${ }^{44}$.

\section{Transducción de señales no clásica}

Los IFN tipo I también pueden señalizar a través de homodímeros de STAT1, pero se asocian más con la vía de señalización mediada por IFN- $\gamma$. Ellos también pueden activar aguas abajo otros heterodímeros y homodímeros 
de STAT, incluidos STAT3, STAT4 y STAT5. También se pueden activar otras vías de señalización que no van a depender de la actividad de JAK ni de STAT, por ejemplo, las proteínas quinasas activadas por mitógeno (MAPK) y la ruta de fosfoinositol 3-quinasa (PI3K), lo que conduce a diversos efectos sobre la célula ${ }^{43,44}$.

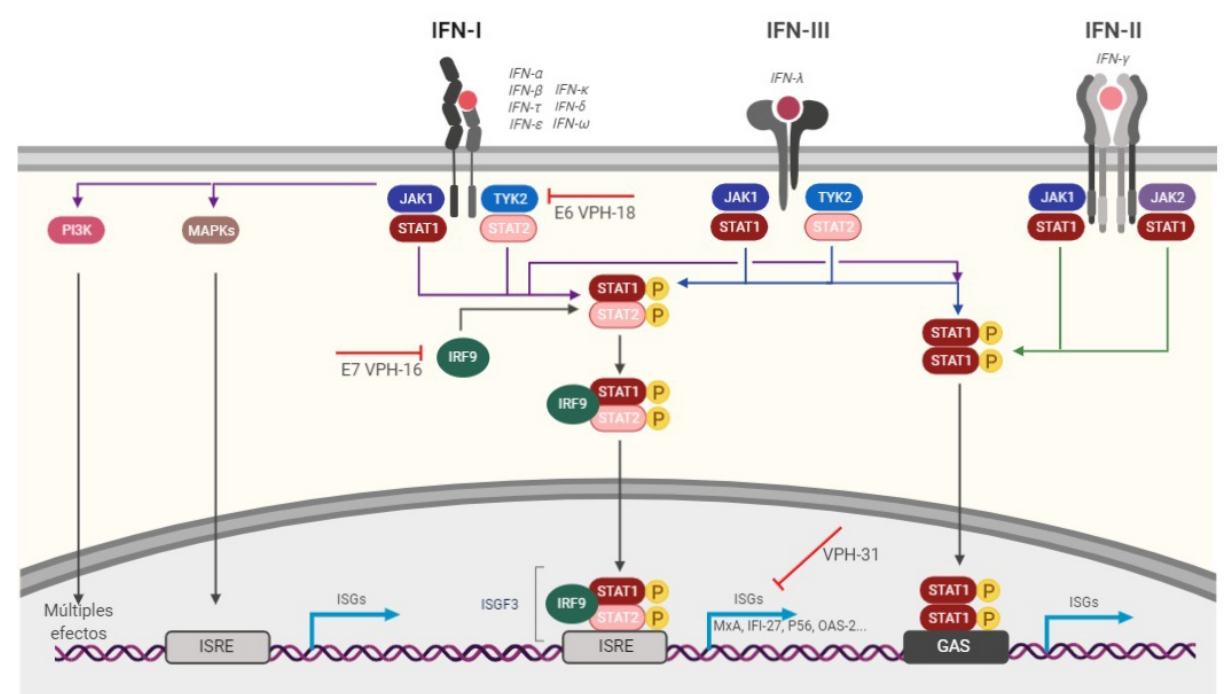

Figura 1. Vías de señalización de los receptores de interferones tipo -I, -II o -III.

En la unión de los IFN a sus receptores, se pueden inducir múltiples vías de señalización aguas abajo, lo que conduce a una amplia gama de efectos biológicos. El transductor de señal canónico y el activador de la transcripción 1 (STAT1) junto con STAT2 y el factor regulador de IFN 9 (IRF9) forman el complejo de señalización ISGF3. Este se une a los elementos de respuesta estimulados por IFN (ISRE) en los promotores de los genes, induciendo una gran cantidad de genes estimulados por IFN (ISG). Los IFN tipo I también pueden señalizar a través de homodímeros de STAT1 u otras vías de señalización independientes de Janus quinasa (JAK) y STAT: las proteínas quinasas activadas por mitógeno (MAPK) y la ruta de fosfoinositol 3-quinasa (PI3K).

\section{Función de los interferones tipo I}

Los IFNs tipo I actúan como puente entre la inmunidad innata y adaptativa. Tienen propiedades antivirales, antiproliferativas, proapoptóticas, antiangiogénicas e inmunoestimuladoras. Además, pueden promover la senescencia e inhibir la función de las células madre en respuesta al acortamiento de los telómeros ${ }^{45-51}$.

La mayoría de los ISGs codificados al final de la vía de señalización no tienen una acción antiviral directa, pero muchos traducen RRP, los cuales identifican moléculas asociadas a virus y dan inicio a la respuesta inmune innata ${ }^{52}$. Es decir, los IFNs pueden afectar indirectamente diferentes procesos virales modulando funciones del sistema inmune por medio de la inducción de citoquinas, las cuales van a activar a las células inmunes no infectadas con el fin de poner en funcionamiento vías que no puedan ser inhibidas rápidamente por los virus ${ }^{53}$. Un ejemplo es aumentar la vigilancia inmunológica regulando positivamente moléculas del complejo mayor de histocompatibilidad clase I, mejorando así la presentación antigénica y activando a los linfocitos $\mathrm{T}$, citotóxicos específicos para reconocer los antígenos virales presentados, estimular la respuesta efectora mediada por células y finalmente conducir a la lisis de las células infectadas ${ }^{54,55}$.

Algunas de las vías bien caracterizadas de la respuesta inmune inducidas por IFN con potencial actividad antiviral directa incluyen cuatro proteínas: la proteína de $15 \mathrm{kDa}$ estimulada por IFN (ISG15), la proteína $\mathrm{Mx}$, la ribonucleasa L (RNasa-L) y la proteína quinasa $\mathrm{R}(\mathrm{PKR})^{28,56}$. Sin embargo, hay más proteínas que funcionan como efectores antivirales importantes como ADAR1 y APOBEC; Teterina y Viperina; TRIM19; la exonucleasa ISG20; y las proteínas IFIT ${ }^{28,57}$. Además, el IFN puede inducir ciertos microARN interferentes con respuestas reguladoras de la infección viral. Estas proteínas van a estar involucradas en diversas funciones que implican la remodelación del citoesqueleto; inducción de la apoptosis; corte, empalme, edición y degradación de ARN viral; regulación en la expresión de proteínas; $y$ modificación postraduccional ${ }^{28,56-58}$. 
La ISG15 es una de las proteínas más importantes que se inducen en las infecciones virales debido a que lleva a cabo diferentes funciones a nivel celular. La ISG15 fue identificada en una vía homóloga a la de la ubiquitina $\mathrm{y}$, al igual que esta, se une de manera covalente a una variedad de blancos proteicos para modular su función en un proceso denominado ISGilación, cuya finalidad es controlar los efectos de la presencia de virus con una maquinaria enzimática que es igualmente regulada por los IFN-I. Sin embargo, la ISGilación no resulta en la degradación de las proteínas marcadas como ocurre en la ubiquitinación, sino que evita la degradación del factor regulador de IFN 3 (IRF3), lo que resulta en una mayor expresión de IFN- $\beta$. Otra de sus funciones es aumentar o disminuir la afinidad y función de proteínas intracelulares; por ejemplo, mediante esta vía se puede regular positivamente el factor de transcripción NF$\kappa \mathrm{B}$ por medio de la unión y supresión de la actividad enzimática de la proteína fosfatasa 1B (PPM1B). Además, ISG15 tiene funciones extracelulares debido a que se secreta y puede actuar como una citoquina. Existen enzimas que hidrolizan la ISG15, de esta manera se puede revertir la ISGilación ${ }^{28}$.

Las proteínas Mx son una familia de GTPasas inducidas por los IFN-I, en humanos están comprendidas por las proteínas MxA y MxB, que se expresan en diversos tipos celulares y se ubican junto al retículo endoplásmico liso, lo que permite su participación en la gemación de vesículas, organogénesis y citocinesis. Debido a que están involucradas en el tráfico vesicular pueden capturar elementos virales como las nucleocápsides y de esta manera suprimir la replicación de los virus tanto nucleares como citoplasmáticos ${ }^{28}$.

La proteína 2'5'-oligoadenilato sintetasa 1 (OAS1) normalmente se encuentra en bajas cantidades en el citoplasma como monómero inactivo a menos que exista una estimulación por parte de los IFN-I. Su función consiste en polimerizar el ATP en oligómeros de adenosina que activan la RNasa-L encargada de degradar los RNAs celulares y virales ${ }^{28}$.

La PKR se expresa constitutivamente en el núcleo y citoplasma. Gracias a los IFN-I se aumenta la cantidad de esta enzima, la cual en presencia de ARNs virales de doble cadena se activa para interferir en la síntesis de proteínas mediante la fosforilación del factor de iniciación de la traducción eucariótica 2 alfa (EIF2 $\alpha)^{28}$.

Por otra parte, los genes estimulados por IFN (ISGs), además de afectar directa e indirectamente diferentes etapas del ciclo replicativo viral, pueden producir importantes efectos modulatorios sobre el metabolismo celular ${ }^{59}$.

En el contexto de la infección por VPH, los queratinocitos han desarrollado mecanismos que le permiten disminuir la propagación de $\mathrm{VPH}$, entre estos, la producción de IFNs que modulan vías metabólicas específicas. Las estrategias de los IFNs incluyen la modulación del flujo de fuentes de carbono exógenas, la inhibición de la biosíntesis del colesterol y el agotamiento de poliaminas, triptófano o sustratos de nucleótidos ${ }^{59}$.

\section{Virus del Papiloma Humano}

\section{Generalidades del virus}

VPH son un grupo de oncovirus pequeños icosaédricos, sin envoltura y con un tamaño aproximado de $55 \mathrm{~nm}$ de diámetro. Su genoma es de ADN de doble cadena y consta de 8000 pares de bases, aproximadamente. Contienen ocho o nueve marcos de lectura abierto que dan lugar a las proteínas tempranas: E1, E2, E4, E5, E6 y E7 con funciones reguladoras y a dos proteínas tardías: L1 y L2, con funciones estructurales en la cápside viral ${ }^{60}$.

Según el análisis de secuencia de ADN, los VPH se dividen en cinco géneros: alfa, beta, gamma, mu y nu. Aquellos que se asocian con el desarrollo de cáncer son los alfa-papilomavirus; estos se han clasificado según su tropismo en tipos cutáneos y mucosos. A su vez, los tipos mucosos, dependiendo de su grado de asociación con el cáncer, pueden catalogarse como de alto o bajo riesgo. Los VPH más estudiados son los alfa-papilomavirus mucosos de alto riesgo que causan $\mathrm{CCU}^{23}$.

\section{Ciclo viral}

El ciclo del VPH está relacionado con el crecimiento y la diferenciación de los queratinocitos de la capa basal del cuello uterino. Estas células se infectan con VPH a través de lesiones y microabrasiones del tejido. La internalización infecciosa tarda varias horas, después el ADN viral se libera de la cápside y se transporta al núcleo como material genético libre o episomas extracromosómicos. La expresión génica temprana está estrechamente controlada en las células epiteliales basales con una amplificación importante del ADN viral. La replicación se produce sólo en células suprabasales que se diferencian, siendo destinadas a la madurez y la senescencia; por lo tanto, no expresan naturalmente la maquinaria replicativa de la que depende el virus para sobrevivir. Para evitar este problema, el VPH codifica 
dos oncoproteínas, E6 y E7; juntas promueven la proliferación celular y previenen la apoptosis. La célula se vuelve permisiva para la replicación viral y se generan cientos o incluso miles de genomas de VPH dentro de una sola célula. Las proteínas de la cápside, L1 y L2, se expresan en las capas más superficiales del epitelio, donde tiene lugar el ensamblaje viral y finalmente se desprenden nuevas partículas virales infecciosas de la superficie epitelial22,60,61.

La expresión de las oncoproteínas E6 y E7 aumenta a medida que avanza el grado de lesión cervical desde neoplasia intraepitelial cervical de grado 1 (NIC-1) a NIC-3. Comúnmente, en las lesiones NIC-1 se conserva la capacidad de completar el ciclo de vida del VPH y de producir partículas virales infecciosas. El aumento de E6 y E7 en la infección por VPH-AR conduce a NIC2 e impulsa la acumulación de cambios genéticos que contribuyen a la progresión del cáncer ${ }^{62}$.

Debido a la desregulación viral que se da en NIC2/-3 se promueve la integración del ADN viral en el genoma de la célula hospedadora. En este proceso, el ADN viral sufre una ruptura de la doble cadena que principalmente se da sobre la región E1/E2 (63-65). E2 es el principal represor de la transcripción de E6 y E7; por lo tanto, en ausencia de este punto crítico de control se va a regular positivamente la transcripción de estos oncogenes ${ }^{61,66}$. (Figura 2)

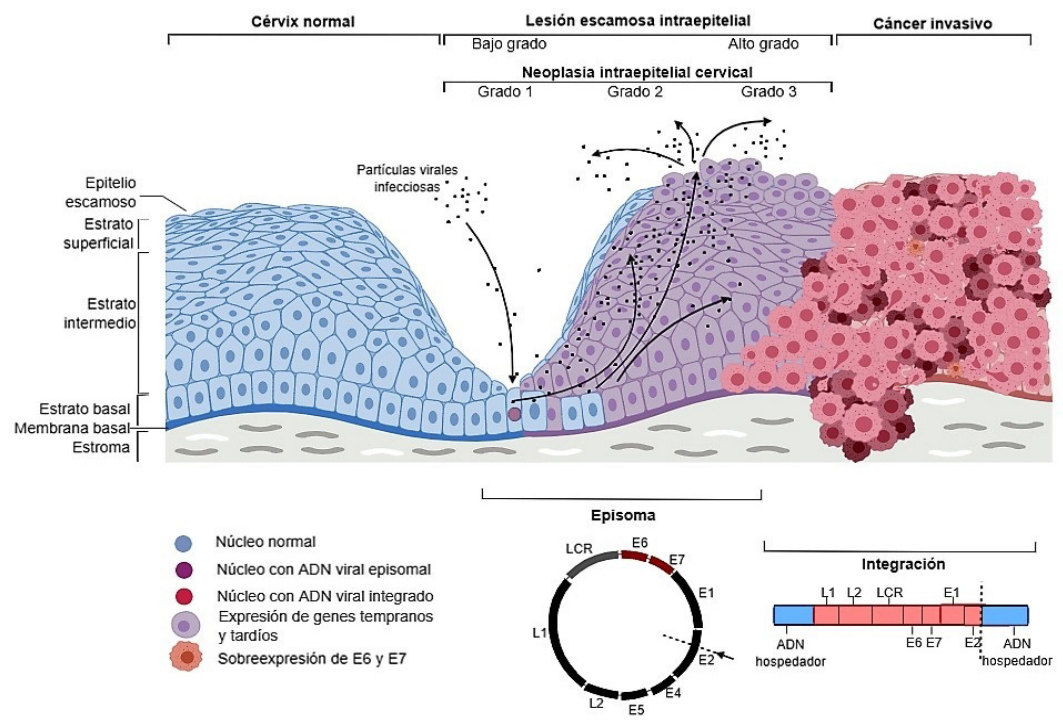

Figura 2. Ciclo de vida de los VPH-AR, organización del genoma e integración viral.

Se da una microabrasión para que entren los viriones de VPH en las células epiteliales mitóticamente activas de la capa basal. La infección es seguida por una fase inicial de amplificación del genoma, y luego por el mantenimiento del episoma viral en un número bajo de copias. La expresión de las proteínas E6 y E7 en las capas epiteliales superiores permite que la célula infectada vuelva a entrar en la fase $S$ y aumente el número de copias del genoma viral. La finalización del ciclo de vida del VPH implica la expresión de las proteínas menor y mayor de la cápside (L2 y L1), la pérdida de control de la célula del ciclo celular y el empaquetamiento del genoma. En la enfermedad cervical, los niveles de expresión de E6 y E7 aumentan desde la neoplasia intraepitelial cervical de grado 1 a 3 (NIC1 a NIC-3). La desregulación viral en NIC-
2, y -3 facilita la integración del episoma en la célula hospedadora, lo que desregula aún más la expresión de los oncogenes E6 y E7. Adaptado de Sanjosé y colaboradores ${ }^{67}$.

\section{Transformación maligna del queratinocito inducida por la infección crónica con VPH}

La persistencia de la infección por VPH-AR es el factor de riesgo más importante para el desarrollo de lesiones premalignas que pueden evolucionar a cáncer ${ }^{68}$. Generalmente, menos del $10 \%$ de las infecciones persisten durante $5-10$ años $^{69}$. Quienes mejoran la replicación y persistencia del VPH son las oncoproteínas E5, E6 y E7 cuya expresión induce la inmortalización y transformación maligna de los queratinocitos infectados del cuello uterino mediante la interacción con diferentes mecanismos celulares. Estas oncoproteínas carecen 
de actividad enzimática, pero actúan como proteínas adaptadoras que reclutan y secuestran las funciones de las proteínas del hospedador ${ }^{70-72}$.

E5 interactúa con algunos factores de proliferación celular, como el factor de crecimiento epidérmico y el factor de crecimiento derivado de plaquetas (EGF y PDGF, por sus siglas en inglés). Además, puede inhibir la apoptosis y la migración del complejo mayor de histocompatibilidad (CMH) a la superficie celular ${ }^{72,73}$.

Por otra parte, E6 interfiere con la función de numerosas proteínas celulares. La unión de E6 de VPH-AR a p53 promueve su degradación al reclutar el complejo enzimático necesario para la ubiquitinación y degradación proteosómica. En ausencia de este regulador negativo del ciclo celular, la proliferación celular no se interrumpe, lo que resulta en mutaciones y anomalías cromosómicas ${ }^{74,75}$. E6 también puede interactuar con quinasas, incrementando la tasa mitótica y puede promover la degradación de proteínas con dominios PDZ, involucradas en la regulación del crecimiento, la proliferación, la polaridad y la adhesión celular $^{76}$. Adicionalmente, E6 induce un estado persistentemente activo de la telomerasa, contribuyendo a la inmortalización de los queratinocitos al mantener la longitud del telómero e incrementando el número de divisiones celulares ${ }^{77}$. E6 también se relaciona con el proceso de carcinogénesis por medio de diferentes oncogenes asociados a la transducción de señales celulares, entre los cuales se encuentra la familia RAS, Notch-1 y c-Myc ${ }^{78-80}$.

Finalmente, E7 codifica una oncoproteína potente que promueve la proliferación y supervivencia celular continua. Regula vías de señalización celular que median la degradación del supresor tumoral de retinoblastoma (pRB), provocando en los queratinocitos un estado de síntesis de ADN, atenuación de la respuesta de senescencia y evasión de los supresores tumorales ${ }^{70,81,82}$. Además, E7 también se une a c-Myc y media su actividad transcripcional, contribuye en la transición epitelio-mesénquima, induce la angiogénesis, desregula el metabolismo celular y promueve la amplificación de los centrosomas, dando lugar a mitosis multipolares e induciendo inestabilidad genómica y mutaciones, eventos que facilitan la progresión oncogénica ${ }^{66,83-87}$.

\section{Evasión del sistema inmunológico por parte del VPH y modulación de vías metabólicas}

VPH ha desarrollado mecanismos para evitar el reconocimiento inicial e interferir en la inmunidad del hospedador. Una de las formas en la que los genotipos de VPH-AR evitan la migración de células inmunitarias al sitio de la infección es regulando negativamente las citocinas proinflamatorias, incluido el Factor de Necrosis Tumoral $\alpha(\mathrm{TNF} \alpha)$ y positivamente las citocinas antiinflamatorias ${ }^{88}$.

Los principales mecanismos de evasión inmunitaria viral para la infección por el VPH están probablemente representados por la evasión del procesamiento y presentación de antígeno, el cambio de una respuesta inmunitaria Th1 a Th2, el silenciamiento de la respuesta inflamatoria a través del reclutamiento de células $\mathrm{T}$ reguladoras y la modulación de la apoptosis ${ }^{3}$. Sin embargo, uno de los mecanismos más importantes que demuestran el secuestro de la respuesta al ADN dañado y la desestabilización inmunitaria consiste en la desregulación de las respuestas al IFN ${ }^{89,90}$.

Como la mayoría de los virus de ADN, los VPH también han desarrollado estrategias efectivas para prevenir la síntesis de IFNs mediante la desregulación de la familia STAT que contiene importantes reguladores de la respuesta inmune innata ${ }^{91,92}$. Sobre la infección viral, E6 y E7 influyen directamente en la expresión del IFN- $\alpha$ e IFN- $\gamma$ porque son capaces de inhibir los factores de regulación del interferón 1 y 9 (IRF1, IRF9) e interfieren directamente con la vía JAK/STAT ${ }^{89}$. El oncogén E6 del VPH-18 funciona como un regulador negativo de la vía JAK/STAT activada por el IFN- $\alpha$ a través de la inhibición de la activación de Tyk2. También Tyk2 se asocia físicamente con E6. Esta interacción Tyk2/E6 es más fuerte en el VPH-18, que en VPH-11 y requiere de los dominios JH6-JH7 de Tyk2 para la unión al IFNAR1 (Figura 3) ${ }^{93}$.

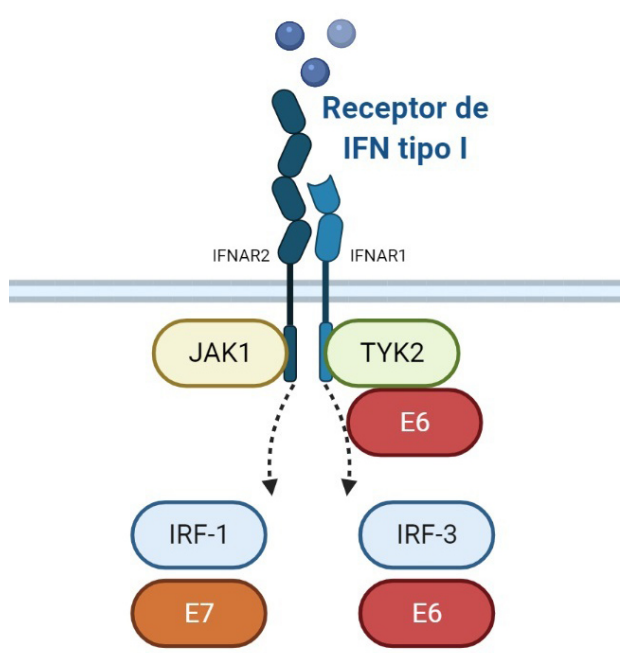

Figura 3. Interferencia de las proteínas de VPH en la respuesta al interferón. E6 se dirige a Tyk2, así como a IRF-3 y E7 se une a IRF-1. 
Por otra parte, los cambios en las vías metabólicas celulares se adaptan a las necesidades específicas de cada virus, una vez se altera la vía metabólica se van a favorecer diferencialmente algunas etapas del ciclo replicativo del virus ${ }^{94}$. En este sentido, el VPH puede reconfigurar el metabolismo celular facilitando desde la entrada del virus a la célula, hasta la replicación y gemación viral ${ }^{95,96}$. Por ejemplo, se ha visto que al adicionar glucosa y glutamina a un cultivo de células HeLa infectadas es posible aumentar hasta en 40000 veces la producción viral ${ }^{97}$. Actualmente, se sabe que los virus modulan el flujo de fuentes de carbono y promueven el cambio hacia la glutaminólisis, la síntesis de ácidos grasos y la glucólisis aeróbica, también conocida como efecto Warburg ${ }^{98}$, con el fin de producir energía, nucleótidos, aminoácidos y ácidos grasos necesarios para aumentar el ensamblaje, la propagación de partículas virales y el mantenimiento de infecciones latentes $^{99}$. Por ejemplo, en la etapa transcripcional de genes tempranos se potenciará la glucólisis, mientras que, si necesita traducir estos genes, se promoverá la glutaminólisis y si lo que se requiere es producir viriones infecciosos, se activará la síntesis de ácidos grasos ${ }^{94}$.

\section{Mecanismos de acción de los IFNs-I vs mecanismos de evasión de VPH}

\section{Interferón alfa}

El IFN- $\alpha$ pertenece a la familia de IFN tipo I, es producido principalmente por leucocitos infectados por virus y participa en la síntesis del complejo mayor de histocompatibilidad clase 1 (MHC-1), encargado de la presentación antigénica durante la infección viral. En humanos existen 13 subtipos de IFN- $\alpha$, compuestos por 189 aminoácidos y codificados por 14 genes no alélicos ubicados en el cromosoma $9^{29,100}$.

Los IFN- $\alpha$ presentan una variedad de funciones biológicas directas o indirectas sobre diferentes células del sistema inmune incluidos los monocitos y las células asesinas naturales $(\mathrm{NK})$, participando principalmente en la expresión antigénica mediada por MHC-1. Debido a su actividad inmunomoduladora, en la última década este interferón ha sido considerado como una prometedora opción terapéutica para el control de enfermedades virales y tumorales, presentando mayor efectividad respecto a los demás tipos de interferón ${ }^{100}$. La vida media de este interferón es corta, por lo que se requieren dosis frecuentes para el control de enfermedades. Sin embargo, se han realizado modificaciones para aumentar su vida media en circulación o prolongar el tiempo de liberación ${ }^{101}$.
Los IFN- $\alpha$ están presentes en las infecciones causadas por VPH. Se ha demostrado que las células dendríticas de tejidos con CCU infectadas con partículas similares al virus VPH-16 (VLP), secretan varias citocinas incluyendo IFN- $\alpha$, IL-6, TNF- $\alpha$ e IL-8 después de la activación de la señalización dependiente de MyD88 (Figura 4) $)^{102-104}$.

Adicionalmente, Sen y colaboradores han comprobado su efecto anti-VPH al evaluar al IFN alfa-n3 y alfa-2b sobre cultivos tridimensionales infectados con VPH$16,-18$ y -31 . Se reportó un efecto inhibitorio sobre la replicación viral desde el 50 hasta el $80 \%$. Este porcentaje se asoció directamente a las concentraciones de IFN implementadas y al genotipo de VPH a tratar ${ }^{105}$.

No obstante, VPH también ha desarrollado mecanismos para protegerse de la acción de los IFN- $\alpha$. Se ha encontrado que E6 de VPH-18 inhibe la vía Jak-STAT inducida por IFN- $\alpha$, debido a su capacidad para interactuar e impedir la activación de Tyk2 (Figura 1) ${ }^{93}$. E6 de VPH18 puede disminuir la transactivación de diferentes ISGs mediados por IFN- $\alpha$ incluidos el ISG-15 y el gen de la proteína 53 inducida por IFN (IFP-53) ${ }^{93}$.

Igualmente, los VPH-AR al mejorar la expresión del regulador del desarrollo relacionado con IFN 1 (IFRD1), disminuyen la acetilación de K310 del NF- $\mathrm{B}$ en los queratinocitos, reduciendo su translocación nuclear y resultando finalmente en una regulación negativa de los IFN- $\alpha$ y de otras citocinas proinflamatorias ${ }^{106}$. También se ha establecido que los dominios CR1 y CR3 de E7 juegan un papel en el deterioro de la acetilación de k310. Al inducir la transactivación del NF- $\mathrm{B}$ con imiquimod, esta fue inhibida por E7, disminuyendo consecuentemente los niveles de IFN- $\alpha$, IL-6 y TNF- $\alpha$ (Figura 4) ${ }^{107}$.

Por otra parte, mediante análisis de microarreglos y análisis de transferencia Northernblot en diferentes líneas celulares infectadas con VPH-31, se descubrió una regulación negativa en el nivel basal de expresión de varios ISGs, incluidos los genes que codifican para MxA, la proteína 27 inducible por IFN- $\alpha$ (IFI-27), la proteína inducible por interferón 56 (P56), OAS-2, STAT-1, entre otros (Figura 1) ${ }^{108}$. Dado que MxA es inducido principalmente por IFN- $\alpha$, se trataron las células con este $\mathrm{IFN}^{109}$. Se encontró que los niveles de MxA y STAT-1 se veían afectados en respuesta al tratamiento en las células positivas para VPH-31. A dosis más altas de IFN- $\alpha$ durante un período prolongado, la vía de transducción de señales de IFN pudo activarse en células positivas para VPH-31 ${ }^{108}$. 
Conociendo las vías por las que VPH puede modificar la respuesta celular mediada por IFN- $\alpha$, facilitar su replicación y evadir la detección por parte del sistema inmune, es posible generar nuevos blancos terapéuticos y optimizar las estrategias terapéuticas actuales contra CCU.

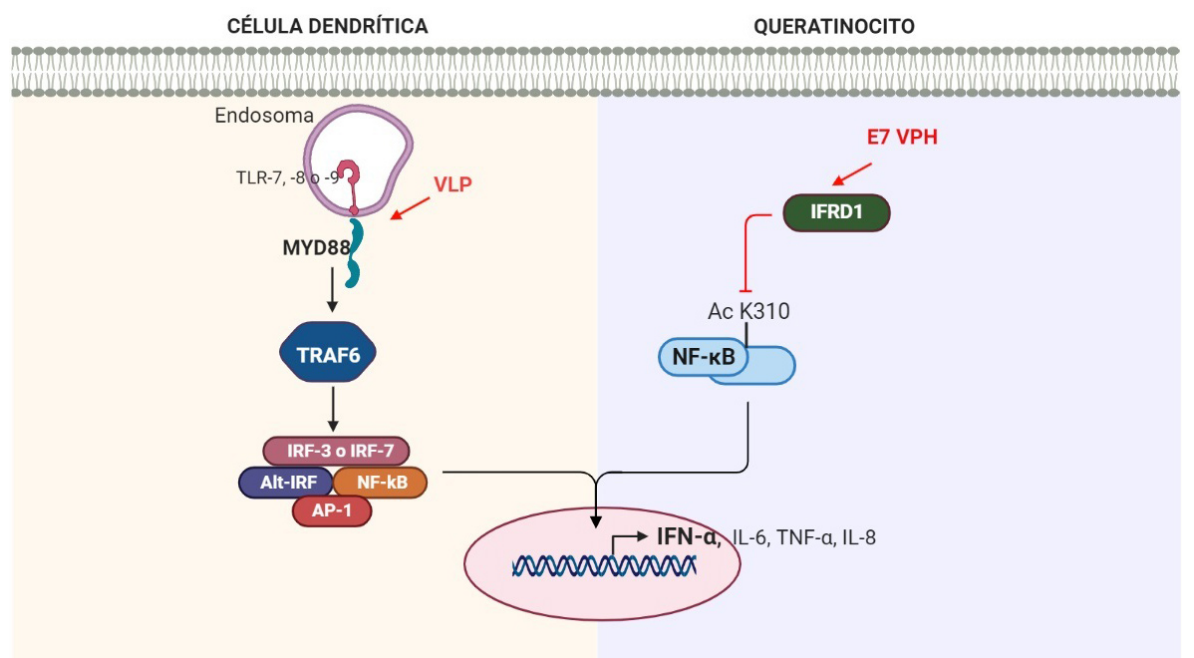

Figura 4. Regulación positiva de IFN- $\alpha$ en células dendríticas de tejidos con CCU infectadas con partículas similares al virus VPH-16 (VLP) (izquierda). Regulación negativa de los IFN- $\alpha$ y de otras citocinas proinflamatorias en los queratinocitos de cuello uterino infectados.

\section{Interferón beta}

Se ha demostrado que tanto IFN- $\alpha$ como IFN- $\beta$ inducen apoptosis en células sensibles y se cree que esto ocurre de manera específica para cada tipo de célula ${ }^{110,111}$. Además, se ha demostrado que IFN- $\beta$ tiene una mayor eficacia en el control de lesiones derivadas del VPH en ensayos clínicos que IFN- $\alpha^{112,113}$.

$\mathrm{Al}$ analizar los efectos de IFN- $\beta$ en las células positivas para VPH-31 se encontró que el tratamiento con IFN- $\beta$ dificulta la entrada de VPH y promueve la eliminación de los episomas de VPH latentes en células infectadas de manera persistente ${ }^{114}$. En otro estudio con queratinocitos cervicales infectados con episomas de VPH-16, se evidenció que el tratamiento con IFN- $\beta$ conduce a una rápida reducción en el número de episomas y a la aparición de integrantes latentes ${ }^{115}$.

Esto sugiere la posibilidad de que el tratamiento con IFN- $\beta$ in vivo pueda seleccionar células que mantengan copias integradas del ADN del VPH. Y debido a que se ha propuesto como una terapia para las lesiones derivadas del VPH, debe manejarse con precaución para evitar la resistencia tras un tratamiento prolongado ${ }^{114,116}$.

Por otro lado, se ha visto que varios miembros de la familia APOBEC3 (A3) citidina desaminasa inducible por IFN- $\beta$ editan el genoma de VPH en queratinocitos cervicales y en lesiones cervicales VPH positivas ${ }^{117}$.
Particularmente A3A, uno de los miembros de esta familia, restringe significativamente la infección por $\mathrm{VPH}^{118}$.

\section{Interferón épsilon}

La estructura del IFN- $\varepsilon$ consta de 192 aminoácidos y solo tiene un $30 \%$ de aminoácidos concordantes con una secuencia consenso de IFN- $\alpha$ y $-\beta$. Sin embargo, se clasificó en la familia de IFN tipo I debido a la localización del gen y porque su señalización se da través de IFNAR1 e IFNAR2 ${ }^{8,119,120}$.

A diferencia de otros IFN tipo I, el IFN- $\varepsilon$ no es inducido por vías conocidas de RRP, sino que se expresa constitutivamente en los pulmones, el cerebro, el intestino delgado y los tejidos reproductivos, y es regulado hormonalmente ${ }^{8,120}$. También se han encontrado grandes diferencias en los perfiles de expresión génica entre los cultivos de células humanas tratadas con IFN- $\varepsilon$ y los tratados con IFN- $\alpha-2 b$. Además, la regulación diferencial de los genes relacionados con el sistema nervioso central por parte del IFN- $\varepsilon$ humano recombinante (rhIFN- $\varepsilon$ ) sugiere un papel del IFN- $\varepsilon$ en el mantenimiento de la estructura y función cerebral ${ }^{121}$.

En un estudio sobre las actividades biológicas del rhIFN- $\varepsilon$ se analizaron las actividades antivirales, antiproliferativas y de activación en células NK. Se determinó que rhIFN- $\varepsilon$ tenía una actividad antiviral 
específica de aproximadamente $6 \times 10^{5} \mathrm{UI} / \mathrm{mg}$ en el sistema WISH/VSV. En cuanto a las actividades antiproliferativas y de promoción de la citotoxicidad de las células NK in vitro, fueron menos potentes al compararse con rhIFN- $\alpha$. También se analizaron los patrones de expresión génica en células tratadas con ambos IFNs, se encontraron 22278 transcriptos humanos modulados en las células tratadas con rhIFN- $\varepsilon$, lo cual fue inferior a lo detectado en las células tratadas con rhIFN- $\alpha^{121,122}$.

Se demostró que IFN- $\varepsilon$ es el único miembro de la familia de IFN tipo I expresado constitutivamente en las células HeLa en bajos niveles y que su expresión está regulada al alta después de la estimulación con TNF- $\alpha$. Se encontró que al silenciar la expresión de IFN- $\varepsilon$ disminuye la fosforilación y expresión de STAT1 y se inhibe la expresión de RIG-I. Proponiendo un mecanismo secuencial en el que el ARNm de IFN- $\varepsilon$ es estabilizado por TNF- $\alpha$, aumentando la síntesis de IFN- $\varepsilon$, el cual se une al receptor de IFN tipo I, aumentando STAT1 y finalmente regulando la expresión de RIG-I'123.

Para evaluar el papel de IFN- $\varepsilon$ en la inmunidad de las mucosas se infectaron ratones vía intranasal con el virus Vaccinia coexpresando IFN- $\varepsilon$. Se observó un rápido aclaramiento del virus que estuvo relacionado con la inducción de una población CD8+CD107a+IFN- $\gamma+$ específica, un gran reclutamiento de linfocitos y un subconjunto intensificado de células T CD8+ y CD4+. Debido a que inicialmente se encontró IFN- $\varepsilon$ en el intestino y tejidos reproductivos, se midió la presencia de células T CD8+ específicas de antígeno en las placas de Peyer, y se encontró que el IFN- $\varepsilon$ fue el responsable de su migración al intestino. Este estudio permite establecer el papel fundamental de IFN- $\varepsilon$ en la mucosa y su posible uso en el control de infecciones pulmonares, intestinales y en enfermedades de transmisión sexual ${ }^{124}$. Además, se ha encontrado que el líquido seminal regula diferencialmente la expresión del IFN- $\varepsilon$ en células epiteliales cérvico-vaginales humanas ${ }^{125}$. Por tanto, es de esperarse que el IFN- $\varepsilon$ tenga un papel protector en el tejido reproductivo.

Fung y colaboradores quisieron determinar si el IFN- $\varepsilon$ era inducido por RRP, como la mayoría de IFN tipo I Sin embargo, tras la estimulación con activadores de RRP, no hubo cambios en la expresión de IFN-e, tampoco con factores de transcripción de la familia IRF, ni tras la infección con Chlamydia muridarum, el virus del bosque Semliki o VHS-2. De manera consistente encontraron que el promotor proximal de IFN- $\varepsilon$ carecía de elementos de respuesta para estas vías; por lo tanto, quisieron comprobar su expresión constitutiva, la cual fue detectada en el útero, el cuello uterino, la vagina y el ovario. Además, la inmunohistoquímica del endometrio demostró la expresión de IFN- $\varepsilon$ en las células epiteliales luminales y glandulares ${ }^{8}$.

Posteriormente, al administrar estrógenos a ratones hembra ovariectomizadas, notaron que la expresión de IFN- $\varepsilon$ aumentó 6 veces, sugiriendo que tiene regulación hormonal. Para comprobar esto en humanos, se analizaron células epiteliales del endometrio de mujeres en diferentes etapas del ciclo menstrual o posmenopáusicas, encontrándose una mayor expresión de IFN- $\varepsilon$ en la fase proliferativa, cuando la concentración de estrógenos es mayor, y niveles indetectables en mujeres posmenopáusicas. De igual manera, IFN- $\varepsilon$ se expresó en líneas celulares derivadas de cáncer de endometrio ${ }^{8}$.

En este estudio también se determinó el papel de IFN- $\varepsilon$ en infecciones virales (VHS-2) y bacterianas (Chlamydia), encontrándose un rol protector en ambos casos: el virus solo fue detectable en ratones sin IFN- $\varepsilon$ y no en el tipo silvestre; igualmente, la detección de bacterias en los frotis vaginales fue mayor en ratones $\sin \mathrm{IFN}-\varepsilon$, mientras que el número de células NK, cuyo papel protector es conocido en esta infección, disminuyó. En este caso, en los ratones de tipo silvestre la expresión de ARN de IFN- $\varepsilon$ no cambió, lo que concuerda con el hecho de que IFN- $\varepsilon$ no está regulado por las vías RRP ${ }^{8}$.

Para confirmar estos hallazgos en humanos, se tomaron muestras cérvico-vaginales de mujeres embarazadas y se midieron las concentraciones de IFN- $\varepsilon$, tanto en mujeres sanas como en mujeres con VHS. Se encontró un aumento de IFN- $\varepsilon$ durante el embarazo, que fue mayor en las mujeres sanas en comparación con aquellas que tenían $\mathrm{VHS}^{126}$.

La relación entre una mayor susceptibilidad a las infecciones del sistema reproductor femenino (SRF) en mujeres que consumen anticonceptivos con progestágenos es conocida ${ }^{127}$. Esta relación podría explicarse por una disminución en los niveles de INF- $\varepsilon$, como se ha visto en los modelos de infección del SRF pretratados con progesterona ${ }^{8}$.

En un estudio sobre el efecto de rhIFN- $\varepsilon$ en la infección por VIH, se evidenció que este afectó diferentes etapas del ciclo de replicación del virus después de la entrada a la célula hasta la traducción a 
proteínas virales, e incluso disminuyó la infectividad de los viriones. De acuerdo con los resultados, la razón fue el aumento de factores de restricción contra VIH causado por INF- $\varepsilon$, cuya potencia de inducción fue parecida a la de IFN- $\alpha$ y $-\beta^{128}$.

Como se ha demostrado, las características únicas de IFN- $\varepsilon$ le otorgan propiedades protectoras contra infecciones de transmisión sexual (ITS) como Chlamydia muridarum o Virus Herpes simplex tipo 2 (VHS-2) $^{8}$. El papel de estas ITS como posibles cofactores en el proceso de carcinogénesis cervical inducido por la infección con $\mathrm{VPH}^{129}$, sumado a la expresión constitutiva de IFN- $\varepsilon$ en las células epiteliales de la mucosa genital, sitio en el que ocurre el primer contacto con agentes infecciosos, aumenta la eficacia de IFN- $\varepsilon$ en el control de estos patógenos, y podría facilitar la creación de estrategias preventivas o de tratamiento contra el cáncer de cuello uterino $(\mathrm{CCU})^{8,123}$.

\section{Interferón kappa}

El IFN- $\kappa$ hace parte de la familia de los IFN tipo I, comparte con estos una homología del $30 \%$ y su gen se encuentra adyacente en el cromosoma 9 traduciendo una citoquina de 180 aminoácidos que se expresa de manera constitutiva y predominante en queratinocitos, a diferencia de otros IFNs como el IFN beta (IFN- $\beta$ ) que se induce en respuesta a estimulación y está presente en diferentes líneas celulares ${ }^{5,130}$.

Muchas de las vías reguladas positivamente por el IFN- $\kappa$ a través de la estimulación de factores de transcripción como STAT1 e IRF1 son importantes en la respuesta antiviral. Gracias a estudios de transcriptoma se conoce que el $71 \%$ de los 1367 genes estimulados por IFN- $\kappa$ coincide con los genes regulados en general por los IFN tipo I. Esto sitúa evidentemente al IFN- $\kappa$ dentro de la familia de los IFN tipo I cuyas funciones antivirales se dan principalmente en los queratinocitos ${ }^{131}$. Sin embargo, también en monocitos y células dendríticas puede estimular la producción y liberación de factor de necrosis tumoral alfa (TNF- $\alpha$ ) y de interleucina-10 (IL-10) e inhibir la IL-12. Debido a su fuerte unión a la heparina, se sugiere que el IFN-א se retiene en el sitio de producción y que activa las vías de señalización por contacto intercelular, estimulando respuestas antivirales localizadas en el sitio de la infección ${ }^{132}$.

Además, por el papel modulador del IFN- $\kappa$ en la respuesta inflamatoria también se han asociado mutaciones en este gen a enfermedades autoinmunes como lupus eritematoso ${ }^{133}$ y artritis reumatoide ${ }^{134}$.
Asimismo, por inmunohistoquímica se ha encontrado que es muy débil o indetectable en la piel sana, en la psoriasis y en la dermatitis atópica, pero está expresado fuertemente en los queratinocitos basales y suprabasales en la dermatitis de contacto alérgica y en el liquen plano ${ }^{135}$.

Actualmente, se ha establecido una asociación entre las lesiones premalignas y cancerosas inducidas por $\mathrm{VPH}$ y la supresión del IFN-א. Por medio de análisis del transcriptoma de células con VPH-AR se encontró una menor expresión de los ISGs causada por la disminución del IFN-к. También se ha determinado que el

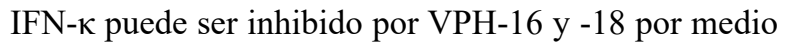
de la proteína E2, encargada de regular la transcripción y replicación del virus ${ }^{136}$.

Se identificó por primera vez la regulación del IFN-k en el contexto de la carcinogénesis inducida por VPH utilizando cultivos primarios de queratinocitos del prepucio humano (QPH) inmortalizados por la expresión de las oncoproteínas E6 y E7, de manera individual o sumada, y células de carcinoma de cérvix $^{13}$. En presencia del oncogén E6 y en las líneas

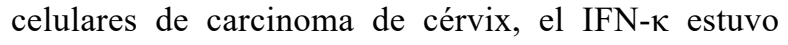
regulado negativamente, contrario a lo encontrado en presencia del oncogén E7 en donde no hubo cambios en su expresión. Además, se evidenció mediante secuenciación por bisulfito que en las células que codifican el oncogén E6 de VPH-16 se induce la metilación de novo en una región que contiene islas de CpGs, adyacentes al sitio del inicio de la transcripción, inhibiendo así epigenéticamente la expresión de

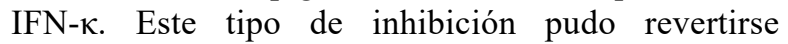
después de demetilar el ADN de las células positivas para E6, E6/E7 y líneas celulares de carcinoma cervical usando inhibidores de la enzima ADN metiltransferasa-1 (DMNT-1) o inhibiendo E6 usando ARN de interferencia, sugiriendo la participación directa de la oncoproteína E6 en el silenciamiento epigenético de IFN-k (Figura 5) ${ }^{13}$.

En contraposición, la re-expresión de IFN-א en células de carcinoma cervical fue relevante a nivel funcional ya que reconstituyó la respuesta antiviral, aumentando el nivel de proteína p53, MxA y de los factores reguladores de INF-1, -7 y -9. Esto se revirtió en células positivas para E7, se suprimió la expresión constitutiva tanto del IFN- $\kappa$ como de p53 utilizando ARN interferentes, encontrándose el efecto inverso en los niveles de estas proteínas indispensables en la respuesta inmediata y tardía mediada por IFN. Todo esto sugiere la existencia de 
un circuito de retroalimentación positiva entre IFN- $\kappa$, p53 y componentes de la vía de señalización del IFN- $\kappa$ para mantener un estado basal antiviral (Figura 5). Al estimar la relevancia clínica de los datos in vitro en biopsias de pacientes con CCU en comparación con biopsias de tejido normal, se corroboró una relación inversa entre la expresión del IFN-א y la transcripción de $\mathrm{VPH}^{13}$, revelando una estrategia novedosa sobre cómo los VPH-AR pueden eliminar la respuesta inmune innata en sus células hospederas.
Adicionalmente, se pudo conocer por análisis de microarreglos de ARN que VPH inhibe a nivel transcripcional tanto al IFN como al TGF $\beta$ A partir de esto se descubrió la relación entre estos dos sistemas y cómo la vía de señalización del TGF $\beta$ induce la desmetilación del promotor del IFN-א por medio de la timina ADN glicosilasa (TDG). De esta manera la transcripción y expresión del IFN- $\kappa$ logra aumentarse cuando el TGF $\beta$. se está expresando, provocando una supresión de la transcripción viral (Figura 5) ${ }^{137}$.
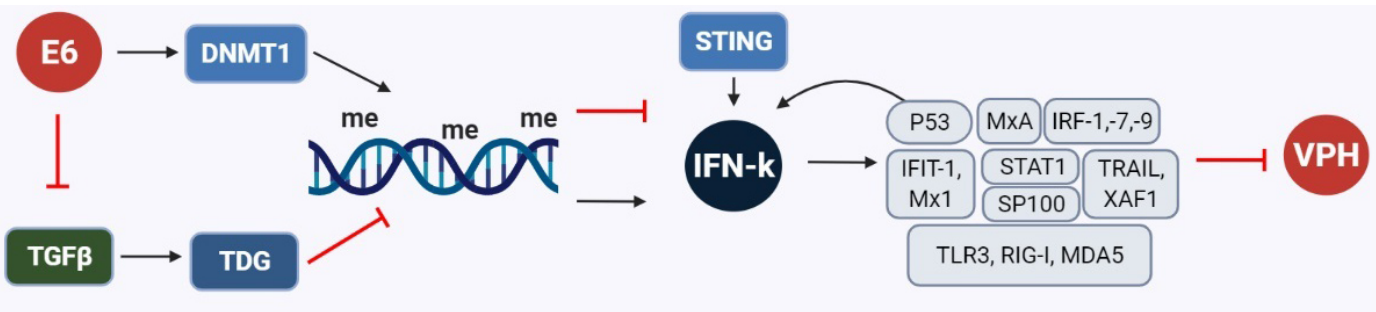

Figura 5. Silenciamiento epigenético de IFN-k y mecanismos regulatorios en la transcripción y expresión de proteínas claves en la respuesta antiviral.

También se ha determinado la expresión del IFN-k en el espectro completo de la carcinogénesis cervical, incluyendo tejido normal, displásico y carcinoma ex vivo de biopsias cervicales completas, estroma y epitelio cervical microdiseccionado ${ }^{138}$. Aquí se encontró una mayor prevalencia y niveles de expresión del ARN mensajero de IFN-k en las biopsias de tejidos con algún grado de enfermedad en comparación con tejidos sanos VPH negativos. Sin embargo, en la microdisección por captura láser se observó que el IFN-k inducido por VPH se expresó a nivel estromal mientras que en el epitelio enfermo el IFN-k estuvo ausente, demostrando que los responsables de la expresión del IFN- $\kappa$ en el estroma afectado son los monocitos y las células dendríticas. En definitiva, en las células de carcinoma cervical no se observó un cambio en la expresión de IFN-k, representando un hallazgo importante que favorece la progresión de la enfermedad ${ }^{138}$.

Los análisis de transcriptomas en queratinocitos con VPH-16, -18 y -31 indican una modulación negativa de diferentes ISG, no solo de aquellos con función directa antiviral o implicados en la señalización del IFN y apoptosis, sino también sobre los que inducen los RRP, que a su vez pueden inducir la expresión de IFN- $\beta$ y $-\lambda$ en los queratinocitos (respectivamente: IFIT1 y Mx1; STAT1; TRAIL y XAF1; TLR3, RIG-I y MDA5)(Figura 5). Esta regulación negativa se asoció principalmente a la acción del oncogén E6, el cual inhibió la expresión constitutiva del IFN- $\kappa$, que al re-expresarse en células VPH positivas resultó en la reactivación de los ISG ${ }^{6}$.
Con el fin de comprender más acerca del mecanismo inhibitorio de E6 sobre el IFN-א se compararon células de carcinoma cervical con células obtenidas de una neoplasia intraepitelial cervical grado 1 (NIC-1). Al activar el oncogén E6, se obtienen 1000 veces menos transcripción de INF-k en células cancerosas, en las que posteriormente al usar 5-Aza-dC solo se pudo activar 9 veces la transcripción. Estos resultados comprueban la importancia del papel de la metilación del ADN en la inhibición de la transcripción del IFN-א. Sin embargo, otros estudios sugieren la posibilidad de otros mecanismos afectados que no permiten un aumento significativo en la transcripción aún en ausencia de metilación del promotor de IFN- $\kappa^{6}$. Además, se demostró que la disminución de la expresión del IFN-א no solo se da en fenotipos malignos, ya que en células no malignas con replicación persistente de VPH la expresión está disminuida ${ }^{6}$.

Complementariamente, se ha sugerido que los VPHAR tienen como blanco al IFN- $\kappa$ para evitar la expresión de proteínas como Sp100 o como IFIT-1, la cual tiene efectos inhibitorios sobre E1 de VPH$16,-18$ y -31 , y puede afectar la oligomerización de E1, la unión al ADN o la propia actividad helicasa, provocando finalmente la inhibición de la replicación del ADN de $\mathrm{VPH}^{131,139,140}$.

Al evaluar el perfil de expresión génica de queratinocitos $\mathrm{VPH}$ positivos se ha demostrado que el dominio de trans-activación amino-terminal 
de la proteína E2 de VPH-16 y -18 disminuye la expresión de STING y de IFN-k y, en consecuencia, se inhibe la transcripción de los ISG. Además, este estudio reveló que al silenciar STING se regulaba la baja la transcripción del IFN-k en un $20 \%$, sugiriendo a STING como un regulador positivo del IFN-k. Igualmente, al evaluar estos hallazgos in vivo, se encontró una supresión de la expresión del IFN-k en tejidos normales VPH positivos y en lesiones escamosas intraepiteliales de bajo grado en comparación con tejidos VPH negativos ${ }^{136}$. Nuevamente, se sugiere que el silenciamiento del IFN-k es crucial en la progresión de lesiones por VPH y que en este suceso están implicadas las proteínas tempranas de VPH.

\section{Conclusiones}

En los últimos años, se ha descubierto que el VPH ha generado mecanismos complejos de patogenicidad a través de los cuales causa un impacto negativo en la respuesta inmune del hospedero, uno de estos es contrarrestar los IFN tipo I.

Se ha estudiado la interacción de los IFNs- $\alpha,-\beta,-\varepsilon,-\kappa$ frente al VPH y se ha encontrado que estos cumplen funciones específicas necesarias para la inmunidad del huésped: el IFN- $\alpha$ es un inductor importante de ISGs y tiene efectos inhibitorios sobre la replicación de VPH; el IFN- $\beta$ puede generar una fuerte reducción en el número de episomas de VPH; el IFN- $\varepsilon$ tiene actividad en las mucosas y aumenta la expresión de células $\mathrm{T}$ citotóxicas, actuando indirectamente en la inmunidad adaptativa frente al VPH; y el IFN- $\kappa$, se expresa constitutivamente en los queratinocitos, inhibe los mecanismos de patogenicidad del VPH y restaura la actividad antiviral, disminuyendo la proliferación celular, la transcripción y las copias del genoma viral.

Es importante desentrañar las bases moleculares de las funciones de los IFN tipo I en la patogénesis mediada por VPH, ya que proporciona información valiosa sobre posibles blancos moleculares que a futuro podrían ser útiles en la creación de terapias más efectivas que puedan bloquear procesos metabólicos específicos y claves para la infección y propagación de VPH, sin que los efectos secundarios de estos nuevos protocolos afecten profundamente el funcionamiento y supervivencia del paciente infectado con VPH.

\section{Referencias}

1. Boccardo E, Lepique AP, Villa LL. The role of inflammation in HPV carcinogenesis. Carcinogenesis. 2010; 31(11): 1905-1912. doi: https://doi.org/10.1093/carcin/bgq176

2. zur Hausen H. Papillomavirus infections - a major cause of human cancers. Biochim Biophys Acta Rev Cancer. 1996; 1288(2): F55-F78. doi: https://doi.org/10.1016/0304-419X(96)00020-0

3. Amador-Molina A, Hernández-Valencia JF, Lamoyi E, Contreras-Paredes A, Lizano M. Role of innate immunity against human papillomavirus (HPV) infections and effect of adjuvants in promoting specific immune response. Viruses. 2013; 5(11): 2624-2642. doi: https://doi.org/10.3390/v5112624

4. Baron S, Dianzani F. The interferons: a biological system with therapeutic potential in viral infections. Antiviral Res. 1994; 24(2-3): 97-110. doi: https:// doi.org/10.1016/0166-3542(94)90058-2

5. LaFleur DW, Nardelli B, Tsareva T, Mather D, Feng $\mathrm{P}$, Semenuk M, et al. Interferon-kappa, a novel type I interferon expressed in human keratinocytes. J Biol Chem. 2001; 276(43): 39765-39771. doi: https://doi.org/10.1074/jbc.M102502200

6. Reiser J, Hurst J, Voges M, Krauss P, Münch P, Iftner T, et al. High-Risk Human papillomaviruses repress constitutive kappa interferon transcription via E6 to prevent pathogen recognition receptor and antiviral-gene expression. J Virol. 2011; 85(21): 11372-11380. doi: https://doi.org/10.1128/ JVI.05279-11

7. Buontempo PJ, Jubin RG, Buontempo CA, Wagner NE, Reyes GR, Baroudy BM. Antiviral activity of transiently expressed IFN- $\kappa$ is cell-associated. J Interf Cytokine Res. 2006; 26(1): 40-52. doi: https://doi.org/10.1089/jir.2006.26.40

8. Fung KY, Mangan NE, Cumming H, Horvat JC, Mayall JR, Stifter SA, et al. Interferon- $\varepsilon$ protects the female reproductive tract from viral and bacterial infection. Science. 2013; 339(6123): 1088-1092. doi: https://doi.org/10.1126/science.1233321

9. Westrich JA, Warren CJ, Pyeon D. Evasion of host immune defenses by human papillomavirus. Vol. 231, Virus Research. Elsevier B.V. 2017; 231: 21-33. doi: https://doi.org/10.1016/j. virusres.2016.11.023

10. zur Hausen H. Cervical carcinoma and human Papillomavirus: On the road to preventing a major human cancer. JNCI J Natl Cancer Inst. 2001; 93(4): 252-253. doi: 10.1093/jnci/93.4.252 
11. DeBerardinis RJ, Lum JJ, Hatzivassiliou G, Thompson CB. The biology of cancer: metabolic reprogramming fuels cell growth and proliferation. Cell Metab. 2008; 7(1): 11-20. doi: https://doi. org/10.1016/j.cmet.2007.10.002

12. Hanahan D, Weinberg RA. Hallmarks of Cancer: The Next Generation. Cell. 2011; 144(5): 646-674. doi: https://doi.org/10.1016/j.cell.2011.02.013

13. Rincon-Orozco B, Halec G, Rosenberger S, Muschik D, Nindl I, Bachmann A, et al. Epigenetic Silencing of Interferon in Human Papillomavirus Type 16-Positive Cells. Cancer Res. 2009; 69(22): 8718-8725. doi: https://doi.org/10.1158/00085472.CAN-09-0550

14. Hong S, Mehta KP, Laimins LA. Suppression of STAT-1 expression by human papillomaviruses is necessary for differentiation-dependent genome amplification and plasmid maintenance. J Virol. 2011; 85(18): 9486-9494. doi: https://doi. org/10.1128/JVI.05007-11

15. Vinay DS, Ryan EP, Pawelec G, Talib WH, Stagg J, Elkord E, et al. Immune evasion in cancer: Mechanistic basis and therapeutic strategies. Semin Cancer Biol. 2015; 35: S185-S198. doi: https://doi. org/10.1016/j.semcancer.2015.03.004

16. Saha A, Kaul R, Murakami M, Robertson ES. Tumor viruses and cancer biology: Modulating signaling pathways for therapeutic intervention. Cancer Biol Ther. 2010; 10(10): 961-978. doi: https://doi.org/10.4161/cbt.10.10.13923

17. Bouvard V, Baan R, Straif K, Grosse Y, Secretan B, El Ghissassi F, et al. A review of human carcinogens--Part B: biological agents. Lancet Oncol. 2009; 10(4): 321-322. doi: https://doi. org/10.1016/S1470-2045(09)70096-8

18. zur Hausen H. The Search for Infectious Causes of Human Cancers: Where and Why (Nobel Lecture). Angew Chemie Int Ed. 2009; 48(32): 5798-5808. doi: https://doi.org/10.1002/anie.200901917

19. McGuire S. World Cancer Report 2014. Geneva, Switzerland: World Health Organization, International Agency for research on cancer, WHO Press, 2015. Adv Nutr.;7(2): 418-419. doi: 10.3945/an.116.012211

20. Organización Mundial de la Salud. Papilomavirus humanos (PVH) y cáncer cervicouterino 2019. https:/www.who.int/es/news-room/fact-sheets/ detail/human-papillomavirus-(hpv)-and-cervicalcancer

21. Stanley M. Pathology and epidemiology of HPV infection in females. Gynecol Oncol. 2010; $117(2$ Suppl): S5-10. doi: https://doi.org/10.1016/j. ygyno.2010.01.024
22. Doorbar J, Quint W, Banks L, Bravo IG, Stoler $\mathrm{M}$, Broker TR, et al. The biology and life-cycle of human papillomaviruses. Vaccine. 2012; 30(Suppl 5): F55-F70. doi: https://doi.org/10.1016/j. vaccine.2012.06.083

23. zur Hausen H. Papillomaviruses in the causation of human cancers - a brief historical account. Virology. 2009; 384(2): 260-265. doi: https://doi. org/10.1016/j.virol.2008.11.046

24. ICO/IARC Information Centre on HPV and Cancer. Human Papillomavirus and Related Diseases Report AMERICAS. 2019. www.hpvcentre.net

25. ICO/IARC Information Centre on HPV and Cancer. Human Papillomavirus and Related Diseases Report COLOMBIA. 2019. www.hpvcentre.net

26. Instituto Nacional de Salud. Boletín Epidemiológico Semanal. Mortalidad perinatal y neonatal. 2018. https://www.ins.gov.co/buscadoreventos/Informesdeevento/C\%C3\%81NCER $\% 20$ DE \% 20 M A M A \% 20 Y \% 20 C U E L L O \% 20 UTERINO_2018.pdf

27. Isaacs A, Lindenmann J. Virus interference. I. The interferon. Proc R Soc London Ser B Biol Sci. 1957; 147(927): 258-267. doi: https://doi. org/10.1098/rspb.1957.0048

28. Sadler AJ, Williams BRG. Interferon-inducible antiviral effectors. Nat Rev Immunol. 2008; 8(7): 559-568. doi: https://doi.org/10.1038/nri2314

29. Pestka S. The interferons: 50 years after their discovery, there is much more to learn. J Biol Chem. 2007; 282(28): 20047-20051. doi: https:// doi.org/10.1074/jbc.R700004200

30. Schoggins JW, Wilson SJ, Panis M, Murphy MY, Jones CT, Bieniasz P, et al. A diverse range of gene products are effectors of the type I interferon antiviral response. Nature. 2011; 472(7344): 481485. doi: https://doi.org/10.1038/nature09907

31. Veer MJ de, Holko M, Frevel M, Walker E, Der $\mathrm{S}$, Paranjape JM, et al. Functional classification of interferon-stimulated genes identified using microarrays. J Leukoc Biol. 2001; 69(6): 912-920. doi: https://doi.org/10.1189/jlb.69.6.912

32. Der SD, Zhou A, Williams BR, Silverman RH. Identification of genes differentially regulated by interferon alpha, beta, or gamma using oligonucleotide arrays. Proc Natl Acad Sci USA. 1998; 95(26): 15623-15628. doi: https://doi. org/10.1073/pnas.95.26.15623

33. Stark GR, Kerr IM, Williams BRG, Silverman RH, Schreiber RD. How cells respond to interferons. Annu Rev Biochem. 1998; 67(1): 227264. doi: 10.1146/annurev.biochem.67.1.227 
34. Marrero-Rodríguez D, Baeza-Xochihua V, Taniguchi-Ponciano K, Huerta-Padilla V, PonceNavarrete G, Mantilla A, et al. Interferon epsilon mRNA expression could represent a potential molecular marker in cervical cancer. Int $\mathrm{J}$ Clin Exp Pathol. 2018; 11(4): 1979-1988. PMCID: PMC6958218.

35. Song J, Guan M, Zhao Z, Zhang J. Type I interferons function as autocrine and paracrine factors to induce autotaxin in response to TLR activation. PLoS One. 2015; 10(8): e0136629. doi: 10.1371/journal.pone.0136629

36. Weiss DL. Interferons and Interferon Inducers. JAMA J Am Med Assoc. 1973; 226(5): 570. doi:10.1001/jama.1973.03230050048027

37. Wheelock EF. Interferon-Like virusinhibitor induced in human leukocytes by Phytohemagglutinin. Science. 1965; 149(3681): 310-311. doi: 10.1126/science.149.3681.310

38. Shiba M, Nonomura N, Nakai Y, Nakayama M, Takayama $\mathrm{H}$, Inoue $\mathrm{H}$, et al. Type-I interferon receptor expression: Its circadian rhythm and downregulation after interferon- $\alpha$ administration in peripheral blood cells from renal cancer patients. Int J Urol. 2009; 16(4): 356-369. doi: https://doi. org/10.1111/j.1442-2042.2009.02265.x

39. van Boxel-Dezaire AHH, Rani MRS, Stark GR. Complex Modulation of Cell Type-Specific Signaling in Response to Type I Interferons. Immunity. 2006; 25(3): 361-372. doi: 10.1016/j. immuni.2006.08.014

40. Kotenko SV, Gallagher G, Baurin VV, LewisAntes A, Shen M, Shah NK, et al. IFN- $\lambda$ s mediate antiviral protection through a distinct class II cytokine receptor complex. Nat Immunol. 2003; 4(1): 69-77. doi: 10.1038/ni875

41. Ank N, West H, Paludan SR. IFN- $\lambda$ : Novel antiviral cytokines. J Interf Cytokine Res. 2006; 26(6): 373379. doi: https://doi.org/10.1089/jir.2006.26.373

42. Vilček J. Novel interferons. Nat Immunol. 2003; 4(1): 8-9. doi: https://doi.org/10.1038/ni0103-8

43. McNab F, Mayer-Barber K, Sher A, Wack A, O'Garra A. Type I interferons in infectious disease. Nat Rev Immunol. 2015; 15(2): 87-103. doi: https://doi.org/10.1038/nri3787

44. Ivashkiv LB, Donlin LT. Regulation of type I interferon responses. Nat Rev Immunol. 2014; 14(1): 36-49. doi: https://doi.org/10.1038/nri3581

45. Le Bon A, Tough DF. Links between innate and adaptive immunity via type I interferon. Curr Opin Immunol. 2002; 14(4): 432-436. doi: 10.1016/ s0952-7915(02)00354-0
46. Foster GR, Rodrigues O, Ghouze F, SchulteFrohlinde E, Testa D, Liao MJ, et al. Different relative activities of human cell-derived interferon- $\alpha$ subtypes: IFN- $\alpha 8$ has very high antiviral potency. J Interf Cytokine Res. 1996; 16(12): 1027-1033. doi: https://doi.org/10.1089/jir.1996.16.1027

47. Ortaldo JR, Herberman RB, Harvey C, Osheroff P, Pan YC, Kelder B, et al. A species of human $\alpha$ interferon that lacks the ability to boost human natural killer activity. Proc Natl Acad Sci USA. 1984; 81(15): 4926-4929. doi: 10.1073/ pnas.81.15.4926

48. Kerbel R, Folkman J. Clinical translation of angiogenesis inhibitors. Nat Rev Cancer. 2002; 2(10): 727-39. doi: 10.1038/nrc905

49. Greiner JW, Hand PH, Schlom J, Noguchi P, Fisher PB, Pestka S. Enhanced Expression of Surface Tumor-associated Antigens on Human Breast and Colon Tumor Cells after Recombinant Human Leukocyte $\alpha$-Interferon Treatment. Cancer Res. 1984; 44(8): 3208-14. PMID: 6744259.

50. Chawla-Sarkar M, Lindner DJ, Liu YF, Williams BR, Sen GC, Silverman RH, et al. Apoptosis and interferons: Role of interferon-stimulated genes as mediators of apoptosis. Apoptosis. 2003; 8(3): 237-249. doi: doi: 10.1023/a:1023668705040

51. Yu Q, Katlinskaya YV., Carbone CJ, Zhao B, Katlinski KV, Zheng $\mathrm{H}$, et al. DNA-DamageInduced Type I Interferon promotes senescence and inhibits stem cell function. Cell Rep. 2015; 11(5): 785-797. doi: 10.1016/j.celrep.2015.03.06952

52. Schneider WM, Chevillotte MD, Rice CM. Interferon-stimulated genes: a complex web of host defenses. Annu Rev Immunol. 2014; 32: 513-545. doi: 10.1146/annurev-immunol-032713-120231 53

53. Davidson S, Maini MK, Wack A. Diseasepromoting effects of type I interferons in viral, bacterial, and coinfections. J Interferon Cytokine Res. 2015; 35(4): 252-264. doi: 10.1089/ jir.2014.0227

54. Hermann P, Rubio M, Nakajima T, Delespesse G, Sarfati M. IFN-alpha priming of human monocytes differentially regulates gram-positive and gram-negative bacteria-induced IL-10 release and selectively enhances IL-12p70, CD80, and MHC class I expression. J Immunol. 1998; 161(4): 2011-2018.

55. Day SL, Ramshaw IA, Ramsay AJ, Ranasinghe C. Differential effects of the type I interferons alpha4, beta, and epsilon on antiviral activity and vaccine efficacy. J Immunol. 2008; 180(11): 7158-7166. doi: 10.4049/jimmunol.180.11.7158 
56. Loeb KR, Haas AL. The interferon-inducible 15$\mathrm{kDa}$ ubiquitin homolog conjugates to intracellular proteins. J Biol Chem. 1992; 267(11): 7806-7813.

57. Vladimer GI, Górna MW, Superti-Furga G. IFITs: Emerging Roles as Key Anti-Viral Proteins. Front Immunol. 2014; 5: 94. doi: 10.3389/ fimmu.2014.00094

58. Sedger LM. microRNA control of interferons and interferon induced anti-viral activity. Mol Immunol. 2013; 56(4): 781-793. doi: 10.1016/j. molimm.2013.07.009

59. Raniga $\mathrm{K}$, Liang $\mathrm{C}$, Raniga $\mathrm{K}$, Liang C. Interferons: Reprogramming the Metabolic Network against Viral Infection. Viruses. 2018; 10(1): 36.

60. Doorbar J. Molecular biology of human papillomavirus infection and cervical cancer. Clin Sci. 2006; 110(5): 525-541. doi: 10.1042/ CS20050369

61. Doorbar J, Egawa N, Griffin H, Kranjec C, Murakami I. Human papillomavirus molecular biology and disease association. Rev Med Virol. 2015; 25(Suppl 1): 2-23. doi: 10.1002/rmv.182262

62. Middleton K, Peh W, Southern S, Griffin H, Sotlar $\mathrm{K}$, Nakahara $\mathrm{T}$, et al. Organization of human papillomavirus productive cycle during neoplastic progression provides a basis for selection of diagnostic markers. J Virol. 2003; 77(19): 1018610201. doi: 10.1128/jvi.77.19.10186-10201.2003

63. McBride AA, Warburton A. The role of integration in oncogenic progression of HPV-associated cancers. PLoS Pathog. 2017; 13(4): e1006211. doi: 10.1371/journal.ppat.1006211

64. Yu T, Ferber MJ, Cheung TH, Chung TKH, Wong YF, Smith DI. The role of viral integration in the development of cervical cancer. Cancer Genet Cytogenet. 2005; 158(1): 27-34. doi: 10.1016/j. cancergencyto.2004.08.021

65. Pett $M$, Coleman N. Integration of high-risk human papillomavirus: a key event in cervical carcinogenesis? J Pathol. 2007; 212(4): 356-67. Available from: http://doi.wiley.com/10.1002/ path.2192

66. Mesri EA, Feitelson MA, Munger K. Human Viral Oncogenesis: A Cancer Hallmarks Analysis. Cell Host Microbe. 2014; 15(3): 266-282. doi: 10.1016/j.chom.2014.02.011

67. de Sanjosé S, Brotons M, Pavón MA. The natural history of human papillomavirus infection. Vol. 47, Best Practice and Research: Clinical Obstetrics and Gynaecology. Bailliere Tindall Ltd; 2018. p. 2-13. doi: 10.1016/j.bpobgyn.2017.08.015
68. Schlecht NF, Kulaga S, Robitaille J, Ferreira S, Santos M, Miyamura RA, et al. Persistent human papillomavirus infection as a predictor of cervical intraepithelial neoplasia. J Am Med Assoc. 2001; 286(24): 3106-3114. doi: 10.1001/ jama.286.24.3106

69. Schiffman M, Castle PE, Jeronimo J, Rodriguez AC, Wacholder S. Human papillomavirus and cervical cancer. Lancet. 2007; 370(9590): 890-907. doi: 10.1016/S0140-6736(07)61416-0

70. Roman A, Munger K. The papillomavirus E7 proteins. Virology. 2013; 445(0): 138-168. doi: 10.1016/j.virol.2013.04.013

71. Vande Pol SB, Klingelhutz AJ. Papillomavirus E6 oncoproteins. Virology. 2013; 445(1-2): 115-37. doi: 10.1016/j.virol.2013.04.026

72. DiMaio D, Petti LM. The E5 proteins. Virology. 2013; 445(1-2): 99-114. doi: 10.1016/j. virol.2013.05.00 73

73. Zhang B, Li P, Wang E, Brahmi Z, Dunn KW, Blum JS, et al. The E5 protein of human papillomavirus type 16 perturbs MHC class II antigen maturation in human foreskin keratinocytes treated with interferon- $\gamma$. Virology. 2003; 310(1): 100-18. doi: 10.1016/s0042-6822(03)00103-X

74. Scheffner M, Werness BA, Huibregtse JM, Levine AJ, Howley PM. The E6 oncoprotein encoded by human papillomavirus types 16 and 18 promotes the degradation of p53. Cell. 1990; 63(6): 11291136. doi: 10.1016/0092-8674(90)90409-8

75. Huibregtse JM, Scheffner M, Howley PM. A cellular protein mediates association of p53 with the E6 oncoprotein of human papillomavirus types 16 or 18. EMBO J. 1991; 10(13): 4129-4135.

76. Nguyen ML, Nguyen MM, Lee D, Griep AE, Lambert PF. The PDZ ligand domain of the human papillomavirus type 16 E6 protein is required for E6's induction of epithelial hyperplasia in vivo. J Virol. 2003; 77(12): 6957-6564. doi: 10.1128/ jvi.77.12.6957-6964.2003

77. Klingelhutz AJ, Foster SA, McDougall JK. Telomerase activation by the E6 gene product of human papillomavirus type 16. Nature. 1996; 380(6569): 79-82. doi: 10.1038/380079a0

78. Spanos WC, Hoover A, Harris GF, Wu S, Strand GL, Anderson ME, et al. The PDZ binding motif of human Papillomavirus type 16 E6 induces PTPN13 loss, which allows anchorage-independent growth and synergizes with ras for invasive growth. J Virol. 2008; 82(5): 2493-2500. doi: 10.1128/ JVI.02188-07 
79. Talora C, Sgroi DC, Crum CP, Paolo Dotto G. Specific down-modulation of Notch1 signaling in cervical cancer cells is required for sustained HPV-E6/E7 expression and late steps of malignant transformation. Genes Dev. 2002; 16(17): 22522263. doi: 10.1101/gad.988902

80. Kinoshita T, Shirasawa H, Shino Y, Moriya H, Desbarats L, Eilers M, et al. Transactivation of prothymosin $\alpha$ and c-myc promoters by human papillomavirus type 16 E6 protein. Virology. 1997; 232(1): 53-61. doi: 10.1006/viro.1997.8536

81. McLaughlin-Drubin ME, Meyers J, Munger K. Cancer associated human papillomaviruses. Curr Opin Virol. 2012; 2(4): 459-466. doi: 10.1016/j. coviro.2012.05.004

82. Moody CA, Laimins LA. Human papillomavirus oncoproteins: Pathways to transformation. Nat Rev Cancer. 2010; 10(8): 550-560. doi: 10.1038/nrc2886

83. Wang YW, Chang HS, Lin CH, Yu WCY. HPV18 E7 conjugates to c-Myc and mediates its transcriptional activity. Int $\mathrm{J}$ Biochem Cell Biol. 2007; 39(2): 402-412. doi: 10.1016/j. biocel.2006.09.006

84. Zwerschke W, Mazurek S, Massimi P, Banks L, Eigenbrodt E, Jansen-Dürr P. Modulation of type M2 pyruvate kinase activity by the human papillomavirus type 16 E7 oncoprotein. Proc Natl Acad Sci U S A. 1999; 96(4): 1291-1296. doi: 10.1073/pnas.96.4.1291

85. Hellner K, Mar J, Fang F, Quackenbush J, Münger $\mathrm{K}$. HPV16 E7 oncogene expression in normal human epithelial cells causes molecular changes indicative of an epithelial to mesenchymal transition. Virology. 2009; 391(1): 57-63. doi: 10.1016/j.virol.2009.05.036

86. McLaughlin-Drubin ME, Münger K. The human papillomavirus E7 oncoprotein. Virology. 2009; 384(2): 335-344. doi: 10.1016/j.virol.2008.10.006

87. Chen W, LiF, Mead L, White H, Walker J, Ingram DA, et al. Human papillomavirus causes an angiogenic switch in keratinocytes which is sufficient to alter endothelial cell behavior. Virology. 2007; 367(1): 168-174. doi: 10.1016/j.virol.2007.05.030

88. Pai SI. Mission impossible: How HPV-associated head and neck cancers escape a primed immune response. Oral Oncol. 2013; 49(8): 723-725. doi: 10.1016/j.oraloncology.2013.03.453

89. Bordignon V, Di Domenico EG, Trento E, D'Agosto G, Cavallo I, Pontone M, et al. How human papillomavirus replication and immune evasion strategies take advantage of the host DNA damage repair machinery. Viruses. 2017; 9(12): 390. doi: $10.3390 / \mathrm{v} 9120390$
90. Beglin M, Melar-New M, Laimins L. Human papillomaviruses and the interferon response. J Interf Cytokine Res. 2009; 29(9): 629-635. doi: 10.1089/jir.2009.0075

91. Fisher C. Recent Insights into the Control of Human Papillomavirus (HPV) Genome Stability, Loss, and Degradation. J Clin Med. 2015; 4(2): 204-30. doi: 10.3390/jcm4020204

92. Hong S, Laimins LA. The JAK-STAT transcriptional regulator, STAT-5, Activates the ATM DNA damage pathway to induce HPV 31 genome amplification upon epithelial differentiation. PLoS Pathog. 2013; 9(4): e1003295. doi: 10.1371/ journal.ppat.1003295

93. Li S, Labrecque S, Gauzzi MC, Cuddihy AR, Wong $\mathrm{AH}$, Pellegrini S, et al. The human papilloma virus (HPV)-18 E6 oncoprotein physically associates with Tyk2 and impairs Jak-STAT activation by interferon- $\alpha$. Oncogene. 1999; 18(42): 5727-5737. doi: 10.1038/sj.onc. 1202960

94. Sanchez EL, Pulliam TH, Dimaio TA, Thalhofer AB, Delgado T, Lagunoff M. Glycolysis, glutaminolysis, and fatty acid synthesis are required for distinct stages of Kaposi's SarcomaAssociated Herpesvirus Lytic replication. J Virol. 2017; 91(10). doi: 10.1128/JVI.02237-16

95. Blanc M, Hsieh WY, Robertson KA, Watterson S, Shui G, Lacaze P, et al. Host defense against viral infection involves interferon mediated downregulation of sterol biosynthesis. Virgin SW, editor. PLoS Biol. 2011; 9(3): e1000598.

96. CivraA, Cagno V, Donalisio M, Biasi F, Leonarduzzi $\mathrm{G}$, Poli G, et al. Inhibition of pathogenic nonenveloped viruses by 25 -hydroxycholesterol and 27-hydroxycholesterol. Sci Rep. 2015; 4(1): 7487. doi: 10.1038/srep07487

97. Eagle H, Habel K. The nutritional requirements for the propagation of poliomyelitis virus by the HeLa cell. J Exp Med. 1956; 104(2): 271-287. doi: 10.1084/jem.104.2.271

98. Warburg O. On the origin of cancer cells. Science. 1956; 123(3191): 309-314. doi: 10.1126/ science.123.3191.309

99. Liberti M V., Locasale JW. The Warburg Effect: How does it benefit cancer cells? Trends Biochem Sci. 2016; 41(3): 211-218. doi: 10.1016/j.tibs.2015.12.001

100.El-Baky NA, Redwan EM. Therapeutic alphainterferons protein: Structure, production, and biosimilar. Prep Biochem Biotechnol. 2015; 45(2): 109127. doi: 10.1080/10826068.2014.907175 
101.Hsu WC, Chien YC, Chang CH, Yuan TT, Lee TW, Hwang JJ. Characteristic comparison between 131I-Interferon- $\alpha$ and 131I-interferonaimmunoglobulin-Fc hybrid protein in rats using molecular imaging. In Vivo (Brooklyn). 2015; 29(4): 445-52. doi: PMID: 26130789.

102. Bontkes HJ, Ruizendaal JJ, Kramer D, Meijer CJLM, Hooijberg E. Plasmacytoid dendritic cells are present in cervical carcinoma and become activated by human papillomavirus type 16 viruslike particles. Gynecol Oncol. 2005; 96(3): 897901. doi: 10.1016/j.ygyno.2004.10.040

103. Lenz P, Lowy DR, Schiller JT. Papillomavirus virus-like particles induce cytokines characteristic of innate immune responses in plasmacytoid dendritic cells. Eur J Immunol. 2005; 35(5): 15481556. doi: 10.1002/eji.200425547

104. Yang R, Murillo FM, Cui H, Blosser R, Uematsu $\mathrm{S}$, Takeda K, et al. Papillomavirus-like particles stimulate murine bone marrow-derived dendritic cells to produce Alpha interferon and Th1 immune responses via MyD88. J Virol. 2004; 78(20): 1115211160. doi: 10.1128/JVI.78.20.11152-11160.2004

105. Sen E, McLaughlin-Drubin M, Meyers C. Efficacy of two commercial preparations of interferon- $\alpha$ on human papillomavirus replication. Anticancer Res. 2005; 25(2A): 1091-1100.

106. Tummers B, Goedemans R, Pelascini LPL, Jordanova ES, Van Esch EMG, Meyers C, et al. The interferon-related developmental regulator 1 is used by human papillomavirus to suppress NFKB activation. Nat Commun. 2015; 13(6): 6537. doi: https://doi.org/10.1038/ncomms7537

107. Richards KH, Wasson CW, Watherston O, Doble R, Eric Blair G, Wittmann M, et al. The human papillomavirus (HPV) E7 protein antagonises an Imiquimod-induced inflammatory pathway in primary human keratinocytes. Sci Rep. 2015; 5:12922. doi: https://doi.org/10.1038/srep12922

108. Chang YE, Laimins LA. Microarray Analysis Identifies Interferon-Inducible Genes and Stat1 as Major Transcriptional Targets of Human Papillomavirus Type 31. J Virol. 2000; 74(9): 4174-4182. doi: 10.1128/jvi.74.9.4174-4182.2000

109. Aebi M, Fäh J, Hurt N, Samuel CE, Thomis D, Bazzigher L, et al. cDNA structures and regulation of two interferon-induced human Mx proteins. Mol Cell Biol. 1989; 9(11): 5062-5072. doi: 10.1128/ mcb.9.11.5062-5072.1989

110. Voelkel JG, Hogan TF. Comparative antiproliferative activity in vitro of natural interferons a and $\beta$ for diploid and transformed human cells. Cancer Res. 1982; 42(12): 4948-53. PMID: 7139598.
111. Zhang H, Koty PP, Mayotte J, Levitt ML. Induction of multiple programmed cell death pathways by IFN- $\beta$ in human non-small-cell lung cancer cell lines. Exp Cell Res. 1999; 247(1): 133-141. doi: 10.1006/excr.1998.4329

112. Gross G. Interferons in Genital HPV Disease. (eds) Genital Papillomavirus Infections. Springer, Berlin, Heidelberg. 1990; 393-412. doi: https://doi. org/10.1007/978-3-642-75723-5_29

113. Gross G. Therapy of human papillomavirus infection and associated epithelial tumors. Intervirology. 1997; 40(5-6): 368-377. doi: 10.1159/000150569

114. Chang YE, Pena L, Sen GC, Park JK, Laimins LA. Long-Term Effect of Interferon on Keratinocytes That Maintain Human Papillomavirus Type 31. J Virol. 2002; 76(17): 8864-8874. doi: 10.1128/ jvi.76.17.8864-8874.2002

115. Herdman TM, Pett MR, Roberts I, Alazawi WOF, Teschendorff AE, Zhang XY, et al. Interferon- $\beta$ treatment of cervical keratinocytes naturally infected with human papillomavirus 16 episomes promotes rapid reduction in episome numbers and emergence of latent integrants. Carcinogenesis. 2006; 27(11): 2341-2353. doi: $10.1093 / \mathrm{carcin} / \mathrm{bgl17}$

116. Warren CJ, Griffin LM, Little AS, Huang IC, Farzan M, Pyeon D. The antiviral restriction factors IFITM1, 2 and 3 do not inhibit infection of human papillomavirus, cytomegalovirus and adenovirus. PLoS One. 2014; 9(5): e96579. doi: 10.1371/journal.pone.0096579

117. Vartanian JP, Guétard D, Henry M, Wain-Hobson S. Evidence for editing of human papillomavirus DNA by APOBEC 3 in benign and precancerous lesions. Science. 2008; 320(5873): 230-233. doi: 10.1126/science. 1153201

118. Monjurul AM, Wakae K, Wang Z, Kitamura K, Liu G, Koura M, et al. APOBEC3A and 3C decrease human papillomavirus 16 pseudovirion infectivity. Biochem Biophys Res Commun. 2015; 457(3): 295-229. doi: 10.1016/j.bbrc.2014.12.103

119. de Weerd NA, Samarajiwa SA, Hertzog PJ. Type I Interferon Receptors: Biochemistry and Biological Functions. J Biol Chem. 2007; 282(28): 20053-20057.

120. Hardy MP, Owczarek CM, Jermiin LS, Ejdebäck M, Hertzog PJ. Characterization of the type I interferon locus and identification of novel genes. Genomics. 2004; 84(2): 331-345.

121.Peng FW, Duan ZJ, Zheng LS, Xie ZP, Gao HC, Zhang $\mathrm{H}$, et al. Purification of recombinant human interferon- $\varepsilon$ and oligonucleotide microarray analysis of interferon- $\varepsilon$-regulated genes. Protein 
Expr Purif. 2007; 53(2): 356-362.

122. Peng F, Gao H, Xie Z, Zhang H, Li Q, Duan Z, et al. Biological activities of recombinant human interferon Epsilon. Zhonghua Shi Yan He Lin Chuang Bing Du Xue Za Zhi. 2005; 19(3): 227-231.

123. Matsumiya T, Prescott SM, Stafforini DM. IFNepsilon mediates TNF-alpha-induced STAT1 phosphorylation and induction of retinoic acidinducible gene-I in human cervical cancer cells. J Immunol. 2007; 179(7): 4542-4549.

124.Xi Y, Day SL, Jackson RJ, Ranasinghe C. Role of novel type I interferon epsilon in viral infection and mucosal immunity. Mucosal Immunol. 2012; 5(6): 610-622.

125. Sharkey DJ, Macpherson AM, Tremellen KP, Robertson SA. Seminal plasma differentially regulates inflammatory cytokine gene expression in human cervical and vaginal epithelial cells. MHR Basic Sci Reprod Med. 2007; 13(7): 491501. doi: https://doi.org/10.1093/molehr/gam028

126. Nickodem C, Criscitiello MF, Bazer F, AbiodunOjo $\mathrm{O}$, Taylor BD. Interferon epsilon in the reproductive tract of healthy and genital herpes simplex virus-infected pregnant women: Results of a pilot study. Am J Reprod Immunol. 2018; 80(3): e12995. doi: 10.1111/aji.12995

127. Baeten JM, Nyange PM, Richardson BA, Lavreys L, Chohan B, Martin HL, et al. Hormonal contraception and risk of sexually transmitted disease acquisition: Results from a prospective study. Am J Obstet Gynecol. 2001; 185(2): 380-385.

128. Garcia-Minambres A, Eid SG, Mangan NE, Pade C, Lim SS, Matthews AY, et al. Interferon epsilon promotes HIV restriction at multiple steps of viral replication. Immunol Cell Biol. 2017; 95(5): 478-483.

129. Smith JS, Muñoz N, Herrero R, Eluf-Neto J, Ngelangel C, Franceschi S, et al. Evidence for Chlamydia trachomatis as a Human Papillomavirus Cofactor in the Etiology of Invasive Cervical Cancer in Brazil and the Philippines. J Infect Dis. 2002; 185(3): 324-331. doi: 10.1086/338569

130. Díaz MO, Pomykala HM, Bohlander SK, Maltepe E, Malik K, Brownstein B, et al. Structure of the Human Type-I Interferon Gene Cluster Determined from a YAC Clone Contig. Genomics. 1994; 22(3): 540-552.

131. Habiger C, Jäger G, Walter M, Iftner T, Stubenrauch F. Interferon Kappa Inhibits Human Papillomavirus 31 Transcription by Inducing Sp100 Proteins. J Virol. 2016; 90(2): 694-704.
132. Nardelli B, Zaritskaya L, Semenuk M, Cho YH, LaFleur DW, Shah D, et al. Regulatory effect of IFN- $\kappa$, a novel type I IFN, on cytokine production by cells of the innate immune system. J Immunol. 2002; 169(9): 4822-4830.

133. Harley ITW, Niewold TB, Stormont RM, Kaufman KM, Glenn SB, Franek BS, et al. The Role of Genetic Variation Near Interferon-Kappa in Systemic Lupus Erythematosus. J Biomed Biotechnol. 2010; 2010: 1-11. doi: 10.1155/2010/706825

134.Liu C, Batliwalla F, Li W, Lee A, Roubenoff R, Beckman E, et al. Genome-wide association scan identifies candidate polymorphisms associated with differential response to anti-TNF treatment in rheumatoid arthritis. Mol Med. 2008; 14(9-10): 575-581. doi: 10.2119/2008-00056.Liu

135. Scarponi C, Nardelli B, Lafleur DW, Moore PA, Madonna S, De Pità O, et al. Analysis of IFN$\kappa$ Expression in Pathologic Skin Conditions: Downregulation in Psoriasis and Atopic Dermatitis. J Interf Cytokine Res. 2006; 26(3): 133-140. doi: 10.1089/jir.2006.26.133

136. Sunthamala N, Thierry F, Teissier S, Pientong C, Kongyingyoes B, Tangsiriwatthana T, et al. E2 Proteins of High Risk Human Papillomaviruses Down-Modulate STING and IFN-א Transcription in Keratinocytes. Zhang L, editor. PLoS One. 2014; 9(3): e91473. doi: https://doi.org/10.1371/ journal.pone.0091473

137. Woodby BL, Songock WK, Scott ML, Raikhy G, Bodily JM. Induction of interferon kappa in human papillomavirus 16 infection by transforming growth factor Beta-Induced promoter demethylation. J Virol. 2018; 92(8): e01714-17. doi: 10.1128/ JVI.01714-17

138. DeCarlo CA, Severini A, Edler L, Escott NG, Lambert PF, Ulanova $\mathrm{M}$, et al. IFN- $\kappa$, a novel type I IFN, is undetectable in HPV-positive human cervical keratinocytes. Lab Investig. 2010; 90(10): 1482-1491. doi: https://doi.org/10.1038/ labinvest.2010.95

139. Stepp WH, Meyers JM, McBride AA. Sp100 provides intrinsic immunity against human papillomavirus infection. MBio. 2013; 4(6): e00845-13. doi: $10.1128 / \mathrm{mBio} .00845-13$

140. Terenzi F, Saikia P, Sen GC. Interferon-inducible protein, P56, inhibits HPV DNA replication by binding to the viral protein E1. EMBO J. 2008; 27(24): 3311-3321. doi: 10.1038/emboj.2008.24 